\title{
Classification and infection mechanism of entomopathogenic fungi
}

\section{Classificacão e mecanismo de infecção dos fungos entomopatogênicos}

\author{
Margy Alejandra Esparza Mora ${ }^{1,2}$, Alzimiro Marcelo Conteiro Castilho², Marcelo Elias Fraga2* \\ | | | | | | | | | | | | | | | | | | | | | | | | | | | | | | | | | | | | | | | | | | | | | | | | | | | | | | | | | | | | | | | | | | | | | | | | | | | | | | | | | | | | | | | | | | | | | | | | | | | | | | | | | | | | | | | | | | | | | | | | | | | | | | | | | | | | | | | | | | | | | | | | | | | | | | | | | | | | | | | | | | | | | | | | | | | | | | | | | | | | | | | | | | | | | | | | | | | | | |
}

\begin{abstract}
Entomopathogenic fungi are important biological control agents throughout the world, have been the subject of intensive research for more than 100 years, and can occur at epizootic or enzootic levels in their host populations. Their mode of action against insects involves attaching a spore to the insect cuticle, followed by germination, penetration of the cuticle, and dissemination inside the insect. Strains of entomopathogenic fungi are concentrated in the following orders: Hypocreales (various genera), Onygenales (Ascosphaera genus), Entomophthorales, and Neozygitales (Entomophthoromycota).
\end{abstract}

KEYWORDS: taxonomy; toxins; enzymes; host.
RESUMO: Os fungos entomopatogênicos são importantes agentes de controle biológico em todo o mundo e têm sido objeto de intensa pesquisa por mais de 100 anos, infectando artrópodes na natureza e podendo ocorrer em níveis enzoóticos ou epizoóticos em suas populaçóes de hospedeiros. O seu mecanismo de infecção envolve a fixação do esporo à cutícula do inseto, seguido da germinação, penetraçáo da cutícula e disseminaçáo interna no inseto. As linhagens dos fungos entomopatogênicos estáo concentradas nas ordens: Hypocreales (vários gêneros), Onygenales (gênero Ascosphaera), Entomophthorales e Neozygitales (Entomophthoromycota).

PALAVRAS-CHAVE: taxonomia; toxinas; enzimas; hospedeiros. 


\section{INTRODUCTION}

Entomopathogenic fungi are a group of phylogenetically diverse, heterotrophic, eukaryotic, unicellular or multicellular (filaments) microorganisms that reproduce via sexual or asexual spores, or both. They have chitinized cells and are generally non-mobile (BADII; ABREU, 2006). The term entomopathogenic refers to those microorganisms that are capable of attacking insects using them as hosts to develop part of their life cycle (DELGADO; MURCIA, 2011), those that reduce pest insect populations to levels that do not cause economic damage to crops (TANZINI et al., 2001), or those that are a mean of control in the reduction of disease vectors (SCHOLTE et al., 2004). They are also defined as facultative or obligate parasites of insects, with a high capacity for sporulation and survival (DELGADO; MURCIA, 2011). They constitute a group of great interest for the biological control of insects. Approximately $80 \%$ of the diseases that occur in insects have a fungus as the causative agent. Practically all insects are susceptible to some of the diseases caused by these fungi, which can lead to death (BATISTA, 1989).

There are fungi that can invade dead insects, called saprophagous, and fungi that infect living insects, called entomophagous (BUTT et al., 2006). Of the estimated 1.5 to 5.1 million species of fungi in the world (HIBBETT et al., 2007), approximately 750 to 1,000 are fungal entomopathogens placed in over 100 genera (ST. LEGER; WANG, 2010). Fungal entomopathogens, thus, constitute the largest number of taxa that are insect pathogens (IGNOFFO, 1973). DE FARIA; WRAIGHT (2007) identified 171 fungal-based products used as biocontrol agents since the 1960s, most of them based on B. bassiana, Beauveria brongniartii, Metarbizium anisopliae, and Isaria fumosorosea.

\section{Classification and phylogeny of entomopathogenic fungi}

Insect pathogens have evolved in most of the major fungal lineages. There are only a few exceptions, such as the Glomeromycota, which contain only mycorrhizal clades (Figure 1). Nutritional modes of the earliest fungi remain poorly understood, but the ability to infect insects is clearly represented in several basally diverging clades, e.g., Blastocladiomycota, Chytridiomycota, and Entomophthoromycota (BOOMSMA et al., 2014). Whereas molecular dating and fossil records have estimated that fungi evolved 0.5 to 1.5 bya, fossil records of Ascomycota and Basidiomycota only date back to the Devonian period some 400 mya (BARBEE; TAYLOR, 2010; LUCKING et al., 2009). The earliest known fossil of an insect pathogenic fungus, a scale insect (Hemiptera) infected by an Ophiocordyceps-like fungus, is from Myanmar amber (100110 mya) (SUNG et al., 2008), and later fossils include a termite (Isoptera) infected by an Entomophthora-like fungus and an ant (Hymenoptera) infected by Beauveria, both from Dominican amber (20-30 mya) (POINAR; THOMAS, 1984).

The approximate number of described insect pathogenic species varies from just a few in the Chytridiomycota, Blastocladiomycota, Kickxellomycotina, and Basidiomycota to a substantial number in the Ascomycota and almost complete dominance in the Entomophthoromycota. The phylogenetic positions of the Ascomycota that harbor most of the known insect pathogens are the Hypocreales and the Onygenales, as detailed in Figure 1, illustrating that insect pathogenic life forms evolved repeatedly in the Ascomycota (SPATAFORA et al., 2007).

The extremely low frequency of insect pathogenic lineages in the Basidiomycota suggests that their adaptive radiation has been driven by ecological functionalities other than parasitizing insects, marking a fundamental difference with the Entomophthoromycota, in which almost all 280 known species are pathogens of arthropod hosts (BALAZY, 1993). Species-level specialization patterns appear to be mostly lineage specific, with the Entomophthoromycota generally having rather narrow host ranges and Ascosphaera (Onygenales) being associated with typical bee nest environments (BOOMSMA et al., 2014). The sexual (teleomorphic) stages of the Hypocreales also appear to be in host specialists, while their asexual (anamorphic) counterparts are generalists. It offers an interesting contrast to the Entomophthorales fungi that are obligatory insect pathogens, which tend to remain host specialists also in their asexual stages. However, some Entomophthorales species have a completely different nutritional mode as parasites of fern gametophytes (Completoria) or desmids, nematodes, and tardigrades (Meristacraceae and Ancylistaceae), whereas others become opportunistic vertebrate pathogens or saprotrophs (e.g., Conidiobolus coronatus) (BALAZY, 1993).

Although the Hypocreales belong to the Sordariomycetes, several basal lineages of the ecologically diverse Pezizomycotina have also evolved insect pathogenic lineages (Figure 1B). These include some species in the Dothideomycetes that are scale insect pathogens, and the Onygenales and Eurotiales orders, which belong to the Eurotiomycetes (KODSUEB et al., 2006). The development of osmophilic traits (e.g., the ability to grow on high sugar content substrates) may have driven the need for habitat specificity (bee brood cells and later bee guts) in the Ascosphaera genus. Members of the Eurotiales mostly appear to have opportunistic life histories as facultative pathogens without much host specialization (SOSA-GOMEZ et al., 2010). The best-studied genera, Aspergillus and Penicillium, are notorious for their production of toxic secondary compounds, which may represent an explicit strategy for poisoning host tissues for later saprophytic exploitation. The opportunistic life form of Eurotiales species may be beneficial during co-infections; that is, rapid host tissue exploitation may allow Aspergillus to outcompete Metarhizium (HUGHES; BOOMSMA, 2004). 


\section{Zygosporic Fungi}

Current phylogenetic studies place the former members of the Zygomycetes into four unaffiliated subphyla (Mucoromycotina, Zoopagomycotina, Kickxellomycotina, and Entomophthoromycotina) (WHITE et al., 2006; HIBBETT et al., 2007). Members of the Mucoromycotina include Mucorales and Mortierellales, which usually are saprobic in soil and dung or weak parasites of plants and animals. A few species such as Sporodiniella umbellata are probably weak pathogens of insects (BENNY, 2009); none, however, is reported as a primary pathogen of healthy insects (MADELIN, 1966). Zoopagomycotina and Kickxellomycotina form a group together with Harpellales (WHITE et al., 2006), containing the orders Dimargaritales (mainly haustorial parasites of Mucorales), Kickxellales (saprobes and non-haustorial parasites of fungi) and without (other) (Harpellales and Asellariales) of fungi associated with the arthropod gut previously placed in the Trichomycetes (LICHTWARDT et al., 2001).
Members of the Harpellales and Asellariales are considered to be gut commensals. Smittium morbosum penetrates through the gut lining and kills mosquito larvae by inhibiting ecdysis (SWEENEY, 1981). In addition, several members of the Harpellales parasitize adult black flies (Simuliidae), filling their ovaries with fungal cysts, so that the flies disperse the fungus when they try to lay their eggs (WHITE et al., 2006). Members of Zoopagomycotina have been divided into two families, with the Zoopagaceae restricted to predaceous forms that trap hosts with adhesives and produce a restricted haustorium; and the Cochlonemataceae, which are parasites of rotifers, amoebae, rhizopods, and other fungi (BENNY, 2009).

The subphylum Entomophthoromycotina contains another lineage of zygosporic fungi, the Entomophthorales (WHITE et al., 2006; HIBBETT et al., 2007; HUMBER, 2008). Many entomopathogens are found in the group (KELLER, 2007), and are classified into the Entomophthoraceae and Neozygitaceae. Some of the species included in these families
A

Entomophthoromycota

Entomophthorales, Neozygitales)

- Ascomycota (Hypocreales)

Ascomycota (Onygenales, Ascosphaera)
B

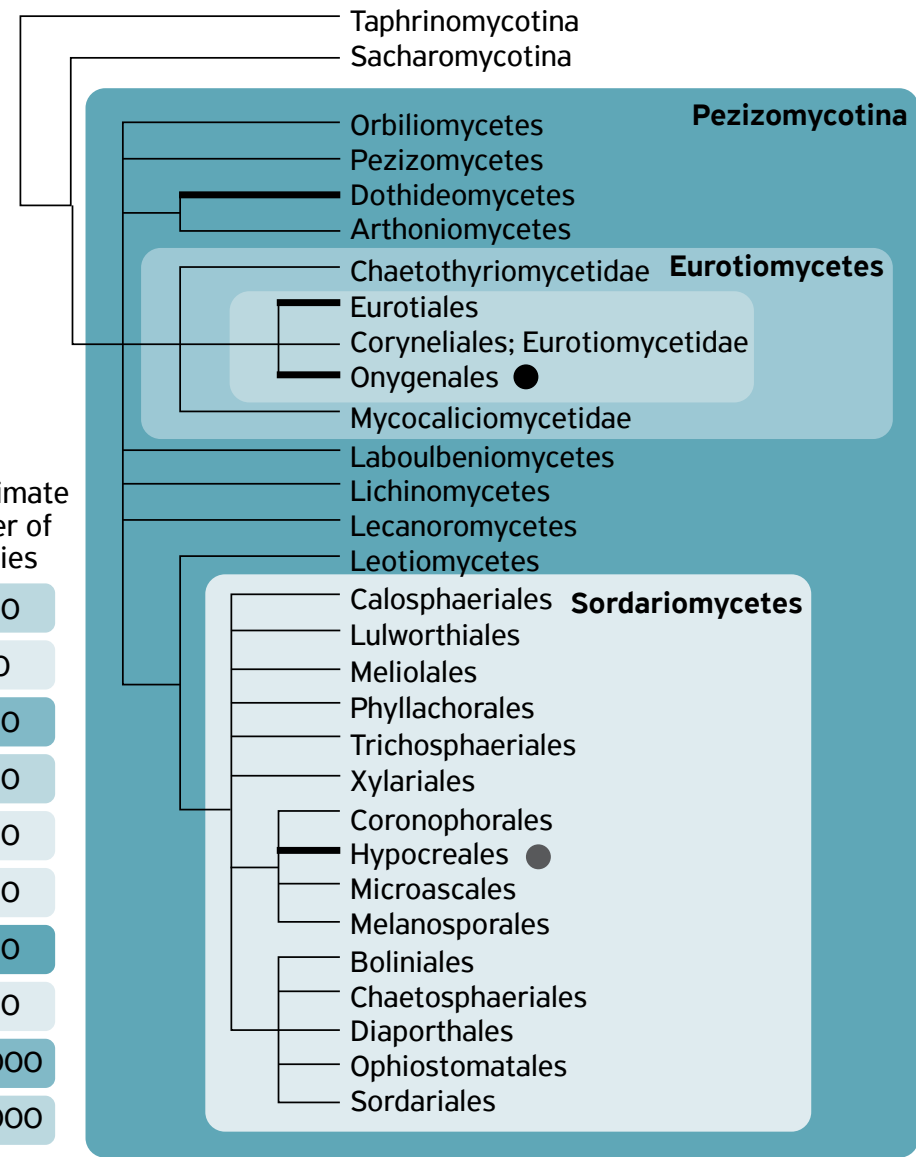

Figure 1. Phylogenetic positions of insect pathogenic fungi. (A) The Kingdom Fungi, with emphasis on phyla with insect pathogens. The numbers represent the approximate number of species described within each (sub)phylum and the shading in ten units in the boxes represents the relative proportions of known species of insect pathogens (highest proportion when blue color is darker). Light grey, black and dark grey dots mark the branches with the most common and best-known insect pathogens. (B) Ascomycota have the highest number of described species and the greatest diversity, including a variety of saprophytic, mutualistic and pathogenic life forms. The thick lines represent orders with insect pathogenic fungi and light grey, black and dark grey dots mark those with the most known insect pathogens: Hypocreales (dark grey, for example, Cordyceps sensulato, Metarhizium and Beauveria) and Onygenales (black, Ascosphaera) (HIBBETT et al., 2007; JAMES et al., 2006; WHITE et al., 2006). 
produce secondary capilliconidia that are effectively dispersed by insects. The Entomophthorales includes the Entomophthora, Pandora, Zoophthora genera, as well as segregate genera. A segregate genus is one that is separate from an existing genus. For example, Entomophaga is a segregate genus of Entomophthora, because some species formerly placed in Entomophthora are now placed in Entomophaga. In addition to species-level specificity, some genera are restricted to certain hosts such as Strongwellsea on flies and Massospora on periodical cicadas (BENNY, 2009).

\section{Phylum Ascomycota}

Ascomycota are classified into three subphyla. Two of these subphyla do not have pathogenic associations with insects. Taphrinomycotina are saprobic or parasitic on plants and vertebrates (HIBBETT et al., 2007). Many ascomycete yeasts (Saccharomycotina) are closely associated with insects for dispersal, and the fungi provide vitamins, enzymes, and other resources for the insect hosts (VEGA; DOWD, 2005). Yeasts, however, are not pathogens or even parasites of insects (KURTZMAN et al., 2011). More than a few different lineages of Pezizomycotina have insect-associated members (HUMBER, 2008; BLACKWELL, 2010). Pezizomycotina are the most numerous and the most morphologically and ecologically complex of the ascomycetes (SCHOCH et al., 2009). The life cycles often have two states, anamorph (asexual state) and teleomorph (sexual state); members of the Hypocreales provide good examples of the phenomenon. In some cases, the sexual state may never or only rarely be produced. Under the new classification, anamorphs are often useful for providing taxonomic information. For example, the anamorphs linked to Torrubiella, a genus whose main range of hosts consists of spiders and scale insects, include the Akanthomyces species, which have a wider range of hosts than Gibellula species, which are restricted to spiders (HODGE, 2003; JOHNSON et al., 2009). Among insect-associated fungi, asexual states often precede the production of sexual states (SUNG et al., 2007). Conidia (asexual spores) that are formed on insect cadaver can be produced directly on conidiophores as in Metarbizium species on adult insects and larvae. In some species of Isaria and Akanthomyces, conidia are formed on synnemata, structures formed by fusion of groups of individual conidiophores. Among the Hypocreales, many of the asexual and sexual states occur separately in time (LUANGSA-ARD et al., 2009).

Both asexual and sexual spores of insect-associated fungi are typically produced on raised structures, enhancing the opportunity for dispersal to a new host. The production of asexual spores may occur in a stroma, with development of the asci and ascospores. Perithecia may be immersed in a stroma, as in Cordyceps militaris, C. ninchukispora, Ophiocordyceps nutans, Elaphe cordyceps paradoxa, and other species (VEGA et al., 2012). Pezizomycotina includes some of the poorly known entomopathogens such as members of the Tubeufiaceae (Dothideomycetes). Species in the Tubeufiaceae have an extensive nutritional range, with many species being saprobic, parasitic on fungi and leaves, or lichen forming with algae (KODSUEB et al., 2006). Species of one genus, Podonectria are pathogens of scale insects (ROSSMAN, 1978). Other entomopathogens include members of the Eurotiomycetes, such as the Ascosphaera (Onygenales) species, which are obligate parasites of larval honey bees (Apis mellifera), and members of the Eurotiales, including certain species of Aspergillus and Penicillium and their relatives (SOSA-GÓMEZ et al., 2010).

Laboulbeniomycetes is an interesting group of insect parasites, though they are not usually considered to be pathogens. The 2,000 known species of the Laboulbeniales order are obligate haustorial ectoparasites of insects and a few other arthropods (WEIR; BLACKWELL, 2005). Two-celled ascospores germinate on the host surface to produce a haustorium from an attached cell, and the outer cell divides producing a perithecium with determinate growth. No mycelium is produced, and the lack of an asexual state in the order is unique among ascomycetes. Beetles and flies are the major hosts for members of the Laboulbeniales (VEGA et al., 2012). A second order, Pyxidiophorales, appears to be mainly mycoparasitic and is also associated with arthropod hosts; these fungi are mycelial and usually have prominent asexual states preceding the development of the sexual state (WEIR; BLACKWELL, 2005).

Hypocreales, members of the Sordariomycetes class, are the most commonly known entomopathogens among the ascomycetes. The former Clavicipitaceae has been divided into three monophyletic families: Clavicipitaceae, Cordycipitaceae, and Ophiocordycipitaceae. The Clavicipitaceae includes the wellknown entomopathogens Aschersonia, Hypocrella, Regiocrella, and Metarbizium (SUNG et al., 2007). Cordycipitaceae contains C. militaris, the genus type, and includes most of the former Cordyceps species, characterized by brightly colored, fleshy stromata. Entomopathogenic asexual states include species of Beauveria, Isaria, Lecanicillium, and other genera. Most Ophiocordycipitaceae members can be distinguished morphologically from the other subphyla due to their often dark stromata and mature ascospores. In addition to Ophiocordyceps species, the Elaphocordyceps genus parasitizes not only insects but also Elaphomyces, a mycorrhizal ascomycete symbiont of trees (SUH et al., 2001). However, spider pathogens are mostly found within the Cordycipitaceae, while scale entomopathogens are common in the Clavicipitaceae. Pathogens of ants, termites, or dipterans, and endo symbionts of plant hoppers are often found in the Ophiocordycipitaceae (SUNG et al., 2007).

\section{Phylum Basidiomycota}

Basidiomycetes often are closely associated with insects as their only nutritional resource and as a habitat, and many insects fertilize and disperse these fungi. Insect associations occur in the three subphyla of basidiomycetes (Pucciniomycotina, Ustilaginomycotina, and Agaricomycotina), but parasites are found only in the Septobasidiales of the Pucciniomycetes (AIME et al., 2006). The Septobasidium 
genus and four additional genera - Auriculoscypha, Uredinella, Coccidiodictyon, and Ordonia — are specific parasites of scale insects, which rarely kill their hosts, but use them as nutrients providers, while keeping them alive (HUMBER, 2008).

\section{Infectious Process}

Insect pathogenic fungi have to meet several host challenges in order to produce enough new infectious spores in every generation to maintain viable populations. Firstly, successful transmission often requires the release of massive spore numbers and/or sticky spore surfaces or substances that maximize adhesion in other ways (VEGA et al., 2012). Secondly, spores should germinate and initiate penetration of the solid insect exoskeleton relatively quickly or survive digestion after oral uptake (Ascosphaera) (COLE; HOCH, 1991; VEGA et al., 2012). Third, fungal cells must proliferate within the hemocoel, muscles, or other tissues of the host's body to collapse the host's immune system so that it subsequently dies (VEGA et al., 2012). Fourth, the fungal pathogen should manage the host cadaver to optimize spore production and dispersal under prevailing environmental conditions (Figure 2) (ROY et al., 2006). Thus, entomopathogenic fungi display several steps in the development of fungal infections.

\section{Adhesion of the spores in the host cuticle and spore germination}

Inoculation occurs by direct contact between infectious cadavers and susceptible hosts or indirectly via airborne spores or spores deposited on vegetation or soil particles (HESKETH et al., 2010). Laboratory infection experiments show that some minimum number of spores is generally needed to achieve predictable infections (INGLIS et al., 2012). Fungi are heterotrophic organisms, but have to absorb the organic compounds produced by other organisms as their primary sources of energy. The first step to infection is the union of fungal propagules to the host cuticle. This binding involves non-specific adhesion mechanisms controlled by the hydrophobic properties of the conidial cell wall (BOUCIAS et al., 1988). The process refers to the interaction between the proteins located in the conidia and the hydrophobic surface of the exoskeleton of the susceptible insects (FANG et al., 2005).

In some taxa of Hypocreales such as Beauveria, Metarhizium, and Isaria, the hydrophobic properties of conidia are due to the presence of cysteine rich proteins called hydrophobins in the cell wall. In contrast, Verticillium lecanii has hydrophilic conidia (INGLIS et al., 2001). This process occurs in three successive phases:

1. adsorption of the spores to the surface through the recognition of specific glycoprotein receptors in the insect;

2. adhesion or consolidation of the interface between the pre-germinated spores and the epicuticle;

3. germination and development until apressory formation initiating the penetration phase (TÉLLEZ-JURADO et al., 2009).

Entomopathogens in the Entomophthorales produce conidia that are evolutionarily derived from sporangia. Conidia of many entomophthorales fungi are forcibly discharged
A
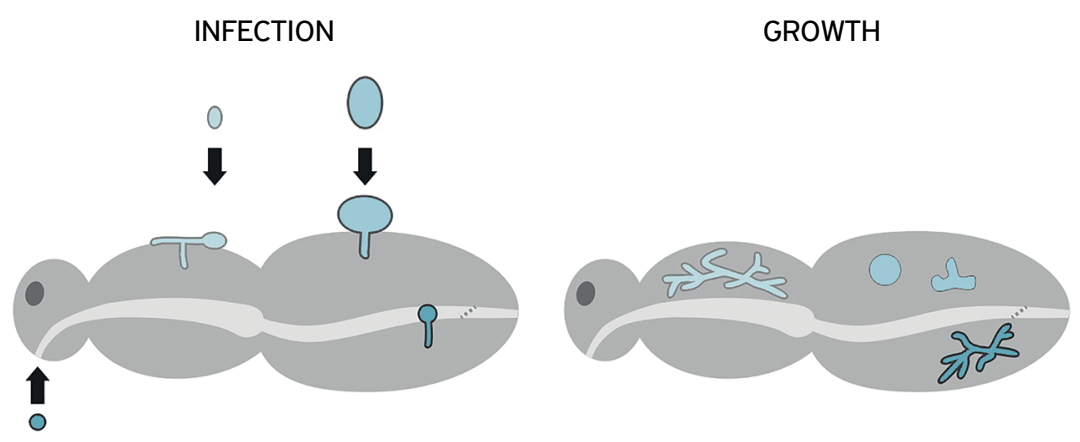

C

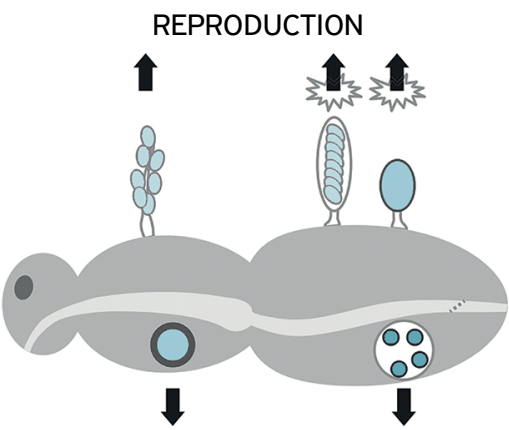

$$
\begin{array}{r}
\text { Pathogenic } \\
\text { fungi }
\end{array}\left\{\begin{array}{l}
\text { Entomophthoromycota (Entomophthorales, Neozygitales) } \\
\text { Ascomycota (Hypocreales) } \\
\text { Ascomycota (Onygenales, Ascosphaera) }
\end{array}\right.
$$

Figure 2. The diagram illustrates the ways in which pathogenic fungi infect arthropod hosts by asexual or sex spores, proliferate and disperse. (A) Infection: Entomophthorales fungi infect mainly by large, sticky conidia that penetrate the cuticle directly, and Hypocreales fungi infect by small conidia, which produce appressorial structures. Ascosphaera spores are also small, enter orally, and infect through the gut epithelium. (B) Growth: most of Hypocreales and Onygenales proliferate through hyphal growth, and Entomophthorales fungi proliferate through protoplasts. (C) Reproduction: asexual conidia of Entomophthorales fungi and sexual ascospores of the Hypocreales are mainly forcibly discharged from the surface of cadavers (arrows upwards to the right), whereas (very large and thick-walled) sexual resting spores of Entomophthorales fungi and asexual conidia of Hypocreales are passively released (upward and downward arrows to the left). Ascosphaera produces only sexual spores that are passively released (downward arrow to the right) (BOOMSMA et al., 2014). 
(PAPIEROK; HAJEK, 1997). Conidia of Entomophthorales are large and typically attach themselves firmly to the cuticle via extra cell wall layers or mucus, which assists the adhesion process (EILENBERG et al., 1986). Some taxa, e.g., species of Neozygites and Zoophthora, also produce elongated capillioconidia that develop at the end of long, slender capilliconidiophores. These propagules become easily detached when touched by an insect and adhere to the cuticle through an adhesive droplet that exudes from the capilliconidium tip (GLARE et al., 1985). HOLDER; KEYHANI (2005) examined the adhesion of aerial conidia, submerged conidia, and blastospores of $B$. bassiana to hydrophobic and hydrophilic surfaces. Their results show that:

1. aerial conidia bind well to hydrophobic surfaces but weakly to hydrophilic surfaces;

2. submerged conidia will bind to both hydrophobic and hydrophilic surfaces;

3. in vitro blastospores will bind strongly to hydrophilic surfaces and weakly to hydrophobic ones.

The process of adhesion between the spore and the insect cuticle is mediated by the presence of molecules synthesized by the fungus, called adhesins. A type of adhesin known as MAD1, which is located on the surface of conidia, has been described in Metarhizium anisopliae. A different adhesin-like protein, MAD2, is involved in M. anisopliae adhesion to plant surfaces, and also appears to be related to the rhizosphere competency of $M$. anisopliae (PAVA-RIPOLL et al., 2011). Disruption of the gene encoding MAD1 affects germination and blastospore formation, signifcantly reducing fungus virulence (WANG; ST. LEGER, 2007).

Germination occurs when the conidium finds favorable conditions of humidity, temperature, and other nutritional, chemical and physical requirements in the cuticle, and can produce penetration structures such as germ tubes and appressorium or a mucilaginous substance that binds to initiate the formation of the germ tube that penetrates through the pores or the outermost layers of the epicuticle (SHAH; PELL, 2003). Once a conidium has attached to the cuticle, an appressorium might form at the end of the germ tube. The appressorium is the infection structure from which penetration into the host occurs through a penetration or infection peg. Some Entomophthorales (e.g., Conidiobolus obscurus, Pandora neoaphidis, P. blunckii, Entomophthora planchoniana, and Batkoa apiculata) do not form appressoria and can penetrate the cuticle directly from the germ tube (HAJEK; DELALIBERA, 2010). Beauveria bassiana, for the germination of conidia, needs an exogenous source of carbon such as chitin and, to a lesser extent, certain fatty acids. In addition, insect epicuticular lipids may be important for binding the fungus to the host cuticle (FERRON, 1978). LECUONA et al. (1997) indicate two possible roles of insect epicuticular lipids and their relationship with entomopathogenic fungi: the first one would be to make the energy sources for the germination of scarce conidia accessible, and the second one could be a specific antifungal activity that may inhibit hyphal growth.
Recently, lipid degradation in the outer layer has been associated as a growth phase prior to fungus penetration (BEYS DA SILVA et al., 2010). It was also suggested the subsequent synthesis of hydrolytic enzymes (proteases, lipases and chitinases, among others) that degrade the cuticle and release nutrients to the fungus (FRANCO et al., 2011).

\section{Hemocoel Penetration}

For the infection to be successful, the entomopathogenic fungus must penetrate the insect cuticle, composed of a network of polysaccharide polymers incorporated into a protein matrix (up to 70\%) (VEGA et al., 2012). The cuticle is divided into three sections (LOCKE, 2001; KLOWDEN, 2007). The outermost layer is called the envelope (also known as the cuticulin layer) and is 10 to $30 \mathrm{~nm}$ in thickness. Underneath the envelope is the epicuticle $(0.5-2 \mathrm{~mm}$ thick), followed by the procuticle (hundreds of times wider than the envelope and epicuticle), which is where chitin and proteins form a matrix. The procuticle can be further divided into an inner layer called the endocuticle (10-200 mm thick), and an outer layer known as the exocuticle. Cuticular proteins can vary across anatomical areas of the insect as well as with the developmental stage of the insect (WILLIS et al., 2005). The epidermal cells are found at the base of the procuticle, and the hemocoel is underneath the epidermal cells.

The cuticle must be breached by mechanical pressure (ZACHARUK, 1970) and via the production of cuticle-degrading enzymes for the fungus to obtain nutrition and eventually colonize the insect (VEGA et al., 2012). The way in which entomopathogenic fungi penetrate the insect depends on the properties of the cuticle, such as thickness, sclerotization, and the presence of antifungal and nutritional substances (CHARNLEY, 2003). The enzymes involved in cuticle degradation include proteases, chitinases, and lipases (MONZÓN, 2001), needed to degrade proteins, chitin, and lipids, respectively. In vitro studies indicate that the digestion of the integument follows a lipase-proteasechitinase sequence (TANADA, KAYA, 1993). The action of the enzyme can be co-aided by the secretion of organic acids such as oxalic acid (KHACHATOURIANS, 1991).

PR1 protease is considered an important virulence factor in Metarhizium anisopliae, and the over-expression of this enzyme in the same fungus reduces the time of death by $25 \%$ in Manduca sexta, compared to those infected with the wild-type genotype (ST. LEGER et al., 1996). Similarly, the over-expression of the gene encoding for Beauveria bassiana chitinase accelerates the death process by $23 \%$ in the insects (FAN et al., 2007). Thus, we can demonstrate the importance of the secretion of these hydrolytic enzymes in the virulence of entomopathogenic fungi, which could be a tool for selecting the best strains for the formulation of biological insecticides.

In addition to invading the insect via cuticular areas and intersegmental membranes, fungal entomopathogens have been reported to invade insects through sense organs and spiracles (ST. LEGER, 1991). For Ascosphaera and Culicinomyces, the 
normal mode of infection is per os (HUMBER, 2009). Because higher humidity is not a problem in the digestive tract, spores can germinate rapidly in this environment, although the digestive fluids can destroy them or degrade germination hyphae. In some cases, the digestion of fungal structures can cause death due to toxicity rather than mycosis (CHARNLEY, 1992).

\section{Hemocoel Replication}

After reaching the hemocoel, most of the fungi carry out a dimorphic transition from mycelium to yeast (Entomophthorales), or, in other words, often without cell wall formation and developing in protoplasts (blastospores), avoiding recognition by circulating hemocytes in hemocoel (VINSON, 1991). The advantages of this cellular form are probably the increase in nutrient acquisition rates and fungal cells can multiply in the hemocoel without being detected by the insect's immune system, which uses cell wall epitopes as detectors. Once they evade the immune system of the insect, septicemia occurs (EILENBERG; MICHELSEN, 1999). The insect can respond to infection through humoral mechanisms (phenoloxidases, lectins, proteins, and defense peptides), cellular ones (phagocytosis, encapsulation), or both. However, the blastospores of some species such as Nomuraea rileyi apparently are not phagocytosed by insect hemocytes, perhaps due to the lack of specific residues on the surface, which makes them unrecognizable by humor lectins (BOUCIAS et al, 1988). When the nutrients from the insect, especially nitrogen sources, are depleted, the yeast phases return to their mycelial growth, as observed in Entomophtora thripidum (FREIMOSER et al., 2003).

Mycosis induces physiological symptoms of abnormalities in the insect such as seizures, lack of coordination, altered behavior and paralysis. Death results from a combination of effects that comprise the physical damage of tissues, toxicity, dehydration of cells due to loss of fluid, and consumption of nutrients (BUSTILLO, 2001). Once inside the insect, fungi have to deal with the immune system response mechanisms for which defensive and immunosuppressive strategies have been developed, such as the production of toxins or structural changes in the cell wall. The fungus must overcome the insect's defense mechanisms to complete the infection process by synthesizing other proteases that degrade the humoral immune system, and also using cyclic depsipeptides, including destruxins, that cause paralysis to the insect in their ability to open the calcium channels, as well as other toxins that damage the muscle system and Malpighi tubules, affecting excretion and hindering their ability to feed and move (PAL et al., 2007).

There are a considerable number of low molecular weight secondary metabolites that have been isolated from insect pathogens, many of which have demonstrated marginal insecticidal activity (GILLESPIE; CLAYDON, 1989). Although less studied, it has also been observed that different macromolecules of a protein nature have a remarkable insecticidal effect, such as the melanizing proteins of B. bassiana (FUGUET; VEY, 2004; FUGUET et al., 2004), a B. sulphurescens glycoprotein (MOLLIER et al.
1994), and hirsutellin A, isolated from Hirsutella thompsonii (WEI-ZHEN et al., 1995). The insecticidal metabolites produced by fungi have several modes of action and in many cases are often the direct cause of insect death, acting in the specialized cells of the immune system to avoid attacking invasive fungal structures (TÉLLEZ-JURADO et al., 2009). Toxin production is a characteristic of most species of entomopathogenic fungi (VEY et al., 2001). Among the toxins produced by M. anisopliae, the destruxins are the most studied ones, for their mode of action, which involves inhibiting the synthesis of DNA, RNA, and proteins in insect cells (PUCHETA et al., 2006).

Finally, when temperature and humidity conditions are favorable, the hyphae can cross the tegument of the insect, occurring to the emergence of the fungus towards the outside. Generally, emergence occurs in the less sclerotic regions of the integument, such as the intersegmental membrane or spiracles, but this will also depend on the host and stage of development. Since hyphae crossing the integument can remain in the vegetative phase and begin the sporulation process (reproductive phase) within 24 to $48 \mathrm{~h}$, depending on the relative humidity and synthesis of antibiotics to prevent the growth of opportunistic organisms (SRIVASTARA et al., 2009), B. bassiana and $B$. brongniartii produce the antibiotic oosporeina. The hyphae form conidiophores, giving rise to asexual spores that are infective units with a dissemination function (CAÑEDO; AMES, 2004). Environmental factors control the production of conidia, their survival, and germination so that they are critical for the development of epizootics (CARRUTHERS; SOPER, 1987). Sporulation normally occurs in cadavers, but can also occur in live insects. The dispersion of spores can be an active or passive process and depends on the characteristics of the spore and sporangium (TANADA; KAYA, 1993).

\section{CONCLUSION}

In general, our understanding of entomopathogenic fungi has evolved by observing dead insects with the aim of understanding how to use these organisms as biological control agents. The mechanism of infection of entomopathogenic fungi is very complex and there are still many questions to be answered. There is no doubt this mechanism is highly specialized, and knowledge of the insect-fungus relationship is essential, both being active organisms. The use of entomopathogenic fungi in agriculture has increased in recent years due to the great potential they have in pest management, representing an efficient alternative to the use of insecticide chemicals, which are considered to be highly harmful to the health of man and ecosystems. Understanding the mechanisms involved in the infection process and the use of new genetic engineering techniques will allow the development of new biological products that are effective for field use and protecting beneficial insect species. 


\section{REFERENCES}

AIME, M.C.; MATHENY, P.B.; HENK, D.A.; FRIEDERS, E.M.; NILSSON, R.H.; PIEPENBRING, M.; MCLAUGHLIN, D.J.; SZABO, L.J.; BEGEROW, D.; SAMPAIO, J.P.; BAUER, R.; WEIB, M.; OBERWINKLER, F.; HIBBETT, D. An overview of the higher level classification of Pucciniomycotina based on combined analyses of nuclear large and small subunit rDNA sequences. Mycologia, v.98, p.896-905, 2006.

BADII, M.H.; ABREU, J.L. Control biológico una forma sustentable de control de plagas. International Journal of Good Conscience, v. 1, p.82-89, 2006.

BALAZY, S. Entomophthorales. Krakow, Poland: Polish Academy of Sciences, v.24, 1993.

BARBEE, M.L.; TAYLOR, J.W. Dating the molecular clock in fungi: How close are we? Fungal Biology, v.24, p.1-16, 2010.

BEYS DA SILVA, W.; SANTI, L.; SCHRANK A.; VAINSTEIN, M.H. Metarhiziumanisopliae lipolytic activity plays a pivotal role in Rhipicephalus (Boophilus) microplus infection. Fungal Biology, v. 1 14, p. 10-15, 2010.

BATISTA, F.A. Controle biológico e o manejo integrado de pragas. Biológico, v.55, p.36-39, 1989.

BENNY, G.L. 2009. Overview of the Zygomycetes. Available from: <http://www.zygomycetes.org>. Access on: 12 Nov. 2015.

BLACKWELL, M. Fungal evolution and taxonomy. BioControl, v.55, p.7-16, 2010.

BOOMSMA, J.; JENSEN, A.; MEYLING, N.; EILENBERG, J. Evolutionary interaction networks of insect pathogenic fungi. Environmental Entomology, v.59, p.467-485, 2014.

BOUCIAS, D.G.; PENDLAND, J.C.; LATGE, J.P. Nonspecific factors involved in attachment of entomopathogenic Deuteromycetes to host insect cuticle. Applied Environmental Microbiology, v.54, p.1795-1805, 1988.

BUSTILLO, A. Hongos en insectos y poszibilidades de uso en el control biológico de plagas en Colombia. In: Seminario Uso de entomopatógenos en Colombia. Sociedad Colombiana de Entomología. Bogotá, p.30-53, 2001.

BUTT, T.M.; WANG, C.; SHAH, F.A.; HALL, R. Degeneration of entomogenous fungi. In: EILENBERG, J.; HOCKKANEN, H.M.T. (Eds.). An Ecological and societal approach to Biological Control, 2006. p.213-226.

CAÑEDO, V.; AMES, T. Manual de Laboratorio para el Manejo de Hongos Entomopatógenos. Lima: Centro International de la Papa (CIP), 2004. 62p.

CARRUTHERS, R.I.; SOPER, R.S. Fungaldiseases. In: FUXA, J.R.; TANADA, Y. (eds.). Epizootiology of Insect Diseases. New York: John Wiley \& Sons, 1987. p.357-416.

CHARNLEY, A.K. Fungal pathogens of insects: cuticle degrading enzymes and toxins. Advances in Botanical Research, v.40, p.241-321, 2003.
CHARNLEY, A.K. Mechanism of fungal pathogenesis in insects with particular reference to locusts. In: LOMER, C.J., PRIOR, C. (eds.). Biological control of locusts and grasshoppers. Melkshan, UK: CAB International, 1992. p.191-199.

COLE, G.T.; HOCH, H.C. (eds). The Fungal Spore and Disease Initiation in Plants and Animals. New York: Plenum, 1991.

DEFARIA, M.R.; WRAIGHT, S.P. Mycoinsecticides and mycoacaricides: a comprehensive list with worldwide coverage and international classification of formulation types. Biological Control, v.43, p.237256, 2007.

DELGADO, P.A.M.; MURCIA, O.P. Hongos entomopatógenos: uma alternativa para la obtención de Biopesticidas. Ambi-Agua, v.6, p.77-90, 2011.

EILENBERG, J.; BRESCIANI, J.; LATGE, J.P. Ultrastructural studies of primary spore formation and discharge in the genus Entomophthora. Journal Invertebrate Pathology, v.48, p.31824, 1986.

EILENBERG, J; MICHELSEN, V. Natural host range and prevalence of the genus Strongwellsea (Zygomycota: Entomophthorales) in Denmark. Journal Invertebrate Pathology, v.73, p.189-198, 1999.

FAN, Y.; FANG, W.; GUO, S.; PEI, X.; ZHANG, Y.; XIAO, Y.; LI, D.; JIN, K.; BIDOCHKA, M.J.; PEI, Y. Increased insect virulence in Beauveria bassiana strains overexpressing an engineered chitinase. Applied Environmental Microbiology, v.73, p.295-302, 2007.

FANG, W.; LENG, B.; XIAO, Y.; JIN, K.; MA, J.; FAN, Y.; FENG, J.; YANG, X.; ZHANG, Y.; PEI, Y. Cloning of Beauveria bassiana chitinase gene Bbchit 1 and its application to improve fungal strain virulence. Applied Environmental Microbiology, v.71, p.363-370, 2005.

FERRON, P. Biological control of insect pests by entomogenous fungi. Annual Review of Entomology, v.23, p.409-442, 1978.

FRANCO, K.; RODRÍGUEZ, S.; CERVANTES, J.; BARRANCO, J. Enzimas y toxinas de hongos entomopatógenos, su aplicación potencial como insecticidas y fungicidas. Sociedades Rurales, Producción y Medio Ambiente, v.11, p.22, 2011.

FREIMOSER, F.M.; GRUNDSCHOBER, A.; TUOR, U.; AEBI, M. Regulation of hyphal growth and sporulation of the insect pathogenic fungus Entomophthora thripidum in vitro. FEMS Microbiology Letters, v.222, p.281-287, 2003.

FUGUET, R.; THÉRAUD, M.; VEY, A. Production in vitro of toxic macromolecules by strains of Beauveria bassiana, and purification of a chitosanase-like protein secreted by a melanizing isolate. Comparative Biochemistry and Physiology Part C. Toxicology $\odot$ Pharmacology, v.138, p.149-161, 2004.

FUGUET, R.; VEY, A. Comparative analysis of the production of insecticidal and melanizing macromolecules by strains of Beauveria spp. in vivo studies. Journal of Invertebrate Pathology, v.85, p. 152-167, 2004. 
GILLESPIE, A.T.; CLAYDON, N. The use of entomogenous fungi for pest control and the role of toxins in pathogenesis. Pesticide Science, v.27, p.203-215, 1989.

GLARE, T.R.; CHILVERS, G.A.; MILNER, R.J. Capilliconidia as infective spores in Zoophthoraphalloides (Entomophthorales). Transactions of the British Mycological Society, v.85, p.463-470, 1985.

HAJEK, A.E.; DELALIBERA, I. Fungal pathogens as classical biological control agents against arthropods. BioControl, v.55, p. 147-158, 2010.

HESKETH, H.; ROY, H.E.; EILENBERG, J.; PELL, J.K.; HAILS, R.S. Challenges in modelling complexity of fungal entomopathogens in semi-natural populations of insects. BioControl, v.55, p.5573, 2010.

HIBBETT, D.S.; BINDER, M.; BISCHOFF, J.F.; BLACKWELL, M.; CANNON, P.F. A higher-level phylogenetic classification of the Fungi. Mycological Research, v. 1 11, p.509-47, 2007.

HODGE, K.T. Clavicipitaceousanamorphs. In: WHITE JR., J.F.; BACON, C.W.; HYWEL-JONES, N.L.; SPATAFORA, J.W. (Eds.). Clavicipitalean Fungi: Evolutionary Biology, Chemistry, Biocontrol, and Cultural Impacts. New York: Marcel Dekker, 2003. p.75-123.

HOLDER, D.J.; KEYHANI, N.O. Adhesion of the entomopathogenic fungus Beauveria (Cordyceps) bassiana to substrates. Applied and Environmental Microbiology, v.7 1, p.5260-5266, 2005.

HUGHES, W.O.H.; BOOMSMA, J.J. Let your enemy do the work: within-host interactions between two fungal parasites of leafcutting ants. The Royal Society's Flagship Biological Research Journal, v.6, p.104, 2004

HUMBER, R.A. Entomogenous fungi. In: SCHAECHTER, M. (Ed.). Encyclopedia of Microbiology. $3^{\text {rd }}$ ed. San Diego: Academic Press, 2009. p.443-456.

HUMBER, R.A. Evolution of entomopathogenicity in fungi. Journal Invertebrate Pathology, v.98, p.262-266, 2008.

IGNOFFO, C.M. Effects of entomopathogens on vertebrates. Annals N.Y. Academic of Sciences, v.217, p.141-172, 1973.

INGLIS, G.D.; ENKERLI, J.; GOETTEL, M.S. Laboratory techniques used for entomopathogenic fungi: Hypocreales. In: LACEY, L.L. (Ed.). Manual of Techniques in Invertebrate Pathology. Amsterdam: Academic, 2012. p.189-253.

INGLIS, G.D.; GOETTEL, M.S.; BUTT, T.M.; STRASSER, H. Use of hyphomycetous fungi for managing insect pests. In: BUTT, T.M.; JACKSON, C.; MAGAN, N. (Eds.). Fungi as Biocontrol Agents Progress, Problems and Potential. Wallingford: CABI, 2001. p.23-69.

JAMES, T.Y.; KAUFF, F.; SCHOCH, C.L.; MATHENY, P.B.; HOFSTETTER, $V$. Reconstructing the early evolution of Fungi using a six-gene phylogeny. Nature, v.443, p.818-822, 2006.

JOHNSON, D.; SUNG, G.H.; HYWELL-JONES, N.L.; LUANGSA-ARD, J.J.; BISCHOFF, J.F.; KEPLER, R.M.; SPATAFORA, J.W. Systematics and evolution of the genus Torrubiella (Hypocreales, Ascomycota). Mycological Research, v.1 13, p.279-289, 2009.
KELLER, S. Arthropod-Pathogenic Entomophthorales: Biology, Ecology, Identification. Luxembourg: Office for Official Publications of the European Communities, 2007.

KHACHATOURIANS, G.G. Physiology and genetics of entomopathogenic fungi. In: ARORA, D.K.; AJELLO, L.; MUKERJI, K.G. (Eds.). Handbook of Applied Mycology. Humans, animals and insects. Marcel Dekker. Nueva York, EEUU, 1991. v.2. p.613-661.

KODSUEB, R.; JEEWON, R.; VIJAYKRISHNA, D.; MCKENZIE, E.H.C.; LUMYONG, P. Systematic revision of Tubeufiaceae based on morphological and molecular data. Fungal Diversity, v.21, p. $105-130,2006$.

KLOWDEN, M.J. Physiological Systems in Insects. $2^{\text {nd }}$ ed. San Diego: Academic Press, 2007.

KURTZMAN, C.P.; FELL, J.W.; BOEKHOUT, T. The Yeasts: A Taxonomic Study. $5^{\text {th }}$ ed. Amsterdam: Elsevier, 2011.

LECUONA, R.; CLEMENT, J.; RIBA, G.; JOULLE, C.; JUAREZ, P. Spore Germination and Hyphal Growth of Beauveria sp. on Insect Lipids. Biological and Microbial Control, v. 1 p.90, 1997.

LICHTWARDT, R.W.; CAFARO, M.J.; WHITE, M.M. The Trichomycetes: Fungal Associates of Arthropods. 2001. Available from: <http:// www.nhm.ku.edu/ fungi/Monograph/Text/Mono.htm>. Access on: 11 Oct. 2015.

LOCKE, M. The Wigglesworth Lecture: Insects for studying fundamental problems in biology. Journal Insect Physiology, v.47, p.495-507, 2001.

LUANGSA-ARD, J.J.; BERKAEW, P.; RIDKAEW, R.; HYWEL-JONES, N.L.; ISAKA, M. A Beauvericin hot spot in the genus Isaria. Mycological Research, v.13, p.1389-1395, 2009.

LUCKING, R.; HUHNDORF, S.; PFISTER, D.H.; PLATA, E.R.; LUMBSCH, H.T. Fungi evolved right on track. Mycologia, v.101, p.810-822, 2009.

MADELIN, M.F. Fungal parasites of insects. Annual Review Entomology, v.11, p.423-448,1966.

MOLLIER, P.; LAGNEL, J.; FOURNET, B.; AÏOUN, A.; RIBA, G.A. Glycoprotein highly toxic for Galleria mellonella larvae secreted by the entomopathogenic fungus Beauveriasulfurescens. Journal of Invertebrate Pathology, v.64, p.200-207, 1994.

MONZÓN, A. Producción, uso y control de calidad de hongos entomopatógenosem Nicaragua. Avances en el fomento de productos fitosanitarios no-sintéticos. Manejo Integrado de Plagas, v.63, p.95-103, 2001.

PAL, S.; ST. LEGER, R.J.; WU, L.P. Fungal peptide destruxin A plays a specific role in suppressing the innate immune response in Drosophila melanogaster. Journal Biological Chemistry, v.282, p.8969-8977, 2007.

PAPIEROK, B.; HAJEK, A.E. Fungi: Entomophthorales. In: LACEY, L.A. (Ed.). Manual of Techniques in Insect Pathology. London: Academic Press, 1997. p.187-212. 
PAVA-RIPOLL, M.; ANGELINI, C.; FANG, W.; WANG, S.; POSADA, F.J.; ST. LEGER, R. The rhizosphere-competent entomopathogen Metarhizium anisopliae expresses a specific subset of genes in plant root exudate. Microbiology, v.157, p.47-55, 2011.

POINAR, G.O.; THOMAS, G.M. Fossil entomogenous fungus from dominican amber. Experientia, v.40, p.578-579, 1984.

PUCHETA, D.M.; FLORES MACIAS, A.; RODRIGUEZ NAVARRO, S.; DE LA TORRE, M. Mecanismo de acción de loshongosentomopatógenos. Interciencia, v.31, p.856-860, 2006.

ROSSMAN, A.Y. Podonectria, a genus in the Pleosporales on scale insects. Mycotaxon, v.7, p.163-182, 1978.

ROY, H.E.; STEINKRAUS, D.; EILENBERG, J.; HAJEK, A.E.; PELL, J.K. Bizarre interactions and endgames: entomopathogenic fungi and their arthropod hosts. Annual Review Entomology, v.51, p.331-357, 2006

SHAH, P.A.; PELL, J.K. Entomopathogenic fungi as biological control agents.Applied Microbiology and Biotechnology, v.61, p.413-423, 2003.

SCHOLTE, E.J.; KNOLS, B.G.J.; SAMSON, R.A.; TAKKEN, W. Entomopathogenic fungi for mosquito control: a review. Journal of Insect Science, v.4, p. 19-24, 2004.

SCHOCH, C.L.; SUNG, G.-H.; LOPEZ-GIRALDEZ, F. The Ascomycota tree of life: a phylum-wide phylogeny clarifies the origin and evolution of fundamental reproductive and ecological traits. Systematic Biologists, v.58, p.224-239, 2009.

SPATAFORA, J.W.; SUNG, G.-H.; SUNG, J.-M.; HYWEL-JONES, N.; WHITE, J.F.R. Phylogenetic evidence for an animal pathogen origin of ergot and the grass endophytes. Molecular Ecology, v. 16, p. 1701-1711, 2007

SOSA-GOMEZ, D.R.; LASTRA, C.C.L.; HUMBER, R.A. An overview of arthropod-associated fungi from Argentina and Brazil. Mycopathologia, v.170, p.61-76, 2010.

SRIVASTARA, N.; MAURYA, P.; SHARMA, P.; MOHAN, L. Prospective role of insecticides of fungal origin: Review. Entomology Research, v.39, p.341-355, 2009

ST. LEGER, R.J.; WANG, C. Genetic engineering of fungal biocontrol agents to achieve efficacy against insect pests. Applied Microbiology and Biotechnology, v.85, p.901-907, 2010.

ST. LEGER, R.J.; JOSHI, L.; BIDOCHKA, M.D. Construction of an improved mycoinsecticide overexpressing a toxic protease. Proceedings of the National Academy of Sciences of the United States of America, v.93, p.6349-6354, 1996.

ST. LEGER, R.J. Integument as a barrier to microbial infections. In: BINNINGTON, K.; RETNAKARAN, A. (Eds.). Physiology of the Insect Epidermis. Australia: CSIRO, 1991. p. 284-306.

SUH, S.-O.; NODA, H.; BLACKWELL, M. Insect symbiosis: derivation of yeast-like endosymbionts within an entomopathogenic lineage. Molecular Biology Evolution, v. 18, p.995-1000, 2001.

SUNG, G.H.; POINAR, G.O.; SPATAFORA, J.W. The oldest fossil evidence of animal parasitism by fungi supports a Cretaceous diversification of fungal-arthropod symbioses. Molecular Phylogenetics and Evolution, v.49, p.495-502, 2008.
SUNG, G.-H.; HYWEL-JONES, N.L.; SUNG, J.-M.; LUANGSA-ARD, J.J.; SRESTHA, B.; SPATAFORA, J.W. Phylogenetic classification of Cordyceps and the clavicipitaceous fungi. Studies in Mycology, v.7, p.55-59, 2007.

SWEENEY, A.W. An undescribed species of Smittium (Trichomycetes) pathogenic to mosquito larvae in Australia. Transactions of the British Mycological Society, v.77, p.55-60, 1981.

TANADA, Y.; KAYA, H.K. Insect Pathology. San Diego: Academic Press, 1993.

TANZINI, M.; ALVES, S.; SETTEN, A.; AUGUSTO N. Compatibilidad de agent estensoactivos com Beauveria bassiana y Metarhizium anisopliae. Manejo Integrado de Plagas, v.59, p.15-18, 2001.

TÉLLEZ-JURADO, A.; CRUZ, R.M.G.; FLORES, M.Y.; ASAFF, T.A.; ARANA CUENCA, A. Mecanismos de acción y respuesta en la relación de hongos entomopatógenos e insectos. Revista Mexicana de Micología, v.30, p.73-80, 2009.

VEGA, F.E., DOWD, P.F. The role of yeasts as insect endosymbionts. In: VEGA, F.E.; BLACKWELL, M. (Eds.). Insect Fungal Associations: Ecology and Evolution. New York: Oxford University Press, 2005. p.21 1-243.

VEGA, F.E.; MEYLING, N.; LUANGSA-ARD, J.; BLACKWELL, M. Fungal Entomopathogens. Insect Pathology, p. 171-220, 2012.

VEY, A.; HOAGLAND, R.E.; BUTT, T.M. Toxic metabolites of fungal biocontrol agents. In: BUTT, T.M.; JACKSON, C.; MAGAN, N. (Eds.). Fungi as Biocontrol Agents. Wallingford: CABI Publishing, 2001. p.31 1-346.

VINSON, S.B. Suppression of the insect immune system by parasitic Hymenoptera. In: PATHAK, J.P.N. (Ed.). Insect Immunity. Dordrecht, Boston and London: Kluwer Academic Publishers, 1991.p.171-187.

WANG, C.; ST. LEGER, R.J. The MAD 1 adhesin of Metarhizium anisopliae links adhesion with blastospore production and virulence to insects, and the MAD2 adhesion enables attachment to plants. Cell eukaryotic, v.6, p.808-816, 2007.

WEI-ZHEN, L.; BOUCIAS, D.G.; MCCOY, C.W. Extraction and characterization of the insecticidal toxin Hirsutellin A produced by Hirsutellathompsonii var. thompsonii. Experimental Mycology, v.19, p.254-262, 1995.

WEIR, A.; BLACKWELL, M. Fungal biotrophic parasites of insects and other arthropods. In: VEGA, F.E.; BLACKWELL, M. (Eds.). Insect-Fungal Associations: Ecology and Evolution. New York: Oxford University Press, 2005. p.119-145.

WILLIS, J.H.; ICONOMIDOU, V.A.; SMITH, R.F.; HAMODRAKAS, S.J. Cuticular proteins. In: GILBERT, L.I.; IATROU, K.; GILL, S.S. (Eds.). Comprehensive Molecular Insect Science. Oxford: Elsevier. 2005. p.79-109.

WHITE, M.M.; JAMES, T.Y.; O'DONNELL, K.; CAFARO, M.J.; TANABE, Y.; SUGIYAMA, J. Phylogeny of the Zygomycota based on nuclear ribosomal sequence data. Mycology, v.98, p.872-84, 2006.

ZACHARUK, R.Y. Fine structure of the fungus Metarhizium anisopliae infecting three species of larval Elateridae (Coleoptera). III. Penetration of the host integument. Journal Invertebrate Pathology, v.15, p.372-396, 1970. 